\title{
ホットプレス窒化ケイ素の強度異方性と破壊源の特徵
}

\author{
伊藤勝 - 酒井清介・山内幸彦・大司達樹・兼松，渉・伊藤正治
}

(名古屋工業技術試験所, 462 名古屋市北区平手町 1-1)

\section{A Study on Strength Anisotropy and the Peculiarity of the Fracture Origin of $\mathrm{HP}-\mathrm{Si}_{3} \mathrm{~N}_{4}$}

\author{
Masaru ITO, Seisuke SAKAI, Yukihiko YAMAUCHI, Tatsuki OHJI, \\ Wataru KANEMATSU and Shoji ITO \\ (Government Industrial Research Institute, Nagoya, 1-1 Hirate-cho, Kita-ku, Nagoya-shi
}

462)

\begin{abstract}
The anisotropic mechanical properties were studied in uniaxially hot-pressed silicon nitride. The flexural strength and Weibull modulus of specimens with longitudinal direction perpendicular to the hot-pressing direction were $22 \%$ and $38 \%$ higher than those of parallel specimens, respectively. The perpendicular specimens had narrower distributions of defect size and 20\% higher critical rupture stress for the apparent same-sized defects than the parallel ones. These differences have been attributed to the shape and orientation of defects.

[Received October 27, 1988; Accepted December 15, 1988]
\end{abstract}

Key-words: Hot pressed silicon nitride, Anisotropic mechanical property, Flexural strength, Weibull modulus, Defect shape

\section{1. 緒言}

窒化ケイ素, 炭化ケイ素等の構造用セラミックスは, ガスタービン用部品など, これまでにない耐熱性, 耐食 性, 耐摩耗性を要求される部品材料として利用されよう としている. 中でも特に高い強度と信頼性を要求される 部品にはホットプレス窒化ケイ素が用いられるが，その 焼成方法が一軸圧縮過程を含むことから，焼結体の持つ 諸特性に異方性が現れることが指摘されてきた のような異方性が, 特に強度上に現れた場合, 部品の信 頼性を損なう可能性があり, 部品設計の際十分な注意が 必要となる.

本報では，イットリア，アルミナ添加ホットプレス窒 化ケイ素の強度の不均一性と異方性の実体を調べるとと もに,これらの破壊源の特徴との関連について調べた。

\section{2. 実験方法}

実験には $\mathrm{Si}_{3} \mathrm{~N}_{4}-\mathrm{Y}_{2} \mathrm{O}_{3}-\mathrm{Al}_{2} \mathrm{O}_{3}$ (10 wt\%) 系ホットプレ ス窒化ケイ素 $(137 \mathrm{~mm} \times 137 \mathrm{~mm} \times 30 \mathrm{~mm})$ のブロック を用い, 図 1 に示すようにプレス方向に垂直な面 $(X-Y$ 平面）内で $X$ 方向を長手方向とする曲げ試験片を 66 本

(A) と，プレス方向（ $Z$ 方向）を長手方向とする試 験片を 72 本（B）の計 138 本を切り出した. 試験片の 加工は，ダイヤモンド切断砥石を用い研削代 $0.3 \mathrm{~mm}$ を 残して切断した後, 表面を粒度 400 のレジノイドボンド ダイヤモンド砥石により試験片の長手方向に研削加工 し, $0.8 \mu \mathrm{m} R_{\max }$ に仕上げ, 加工が強度の測定結果に及

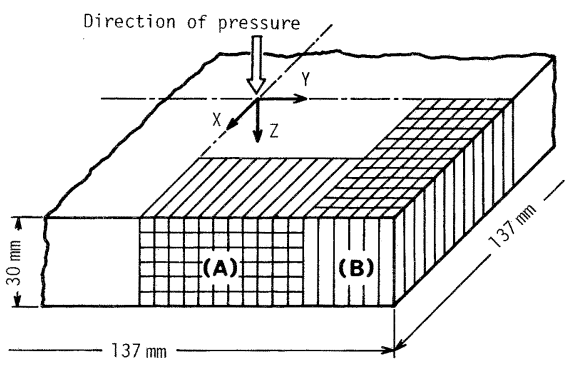

Fig. 1. Specimens cut perpendicularly to hotpressing direction (A) and parallel to that direction (B).

ぼす影響を除いた。

一方, 作製した試験片 $(3 \mathrm{~mm} \times 3 \mathrm{~mm} \times 28 \mathrm{~mm})$ の強 度はスパン $20 \mathrm{~mm} の 3$ 点曲げ試験によって測定し, 上 記のブロック内での試験片の位置や切り出し方向による 強度の差を求めた。また, 強度測定後の試験片の破面観 察を行い, 破壊源の位置, 寸法亡強度の関係を求め, ホッ トプレス窒化ケイ素の強度異方性の原因について検討し た。

\section{3. 実験結果及び考察}

図 2 は, 図 1 に示すブロック内での位置と強度の関係 を示したものである. 図2の（A）はプレス方向に垂直 な面内から切り出した試験片を $30 \mathrm{~mm}$ のブロック厚さ 方向（プレス方向）に 6 層に分け, 各層の 11 本の平均 


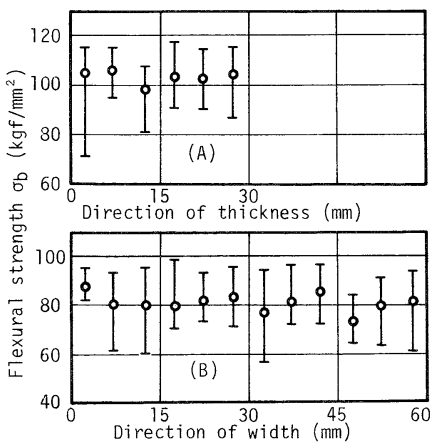

Fig. 2. Relation between the strength and the position of specimens.

(A) Perpendicular specimens,

(B) Parallel specimens

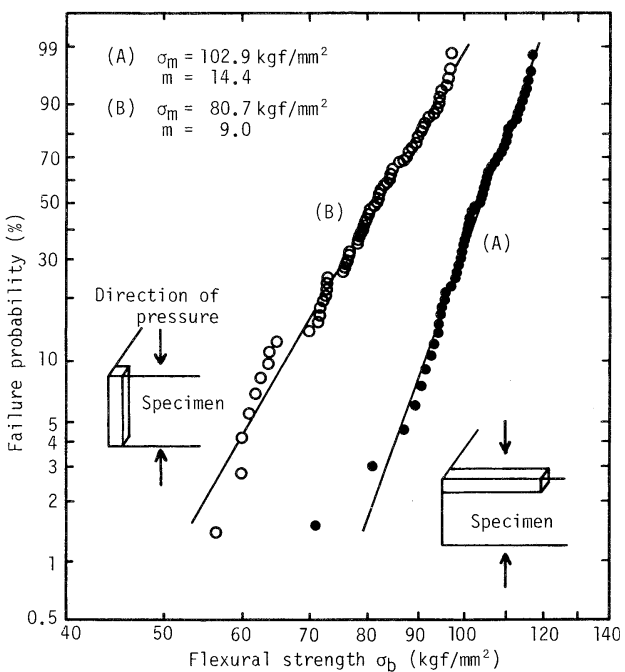

Fig. 3. The flexural strength distribution of hotpressed silicon nitride.

強度とそのばらつきの範囲を示す．また，（B）はプレ ス方向に切り出した試験片について切り出し位置（X 方向）に対する強度の変化を調べたもので, 各位置の強 度は $Y-Z$ 面内の 6 本の平均強度とそのばらつきの範囲 を示す。 (A)，（B）とも強度のばらつきの大きさに比 べて, 平均強度の変動は極めて小さく, 板厚方向, 板面 内方向とも試験片の切り出し位置による強度差はほとん ぼないと考えられる。

しかし，(A）及び（B）の各位置での強度のばらつ きは試験片数を考慮すれば前者に比べて後者で大きいこ とが分かる．また，両者ではその強度值にかなりの差が 見られる。 そこでプレス方向に垂直な面内から切り出し た試験片 66 本 $(\mathrm{A})$ と, プレス方向に切り出した試験 片 72 本 (B) をそれぞれまとめて図 3 にワイブルプロッ トで示す. (A)に比べて (B)の強度は, 平均強度で $22 \%$, ワイブル係数で $38 \%$ の低下が見られる。すなわち，同
一ブロックからの試験片でも切り出す方向によって強度 特性はかなり異なった值を示すことになる。

このような強度低下の原因としては，ホットプレス焼 結法の特徵である焼結時の一軸圧縮により，窒化ケイ素 粒子の圧縮方向に垂直な面内への配向あるいは粒成長の ため，この面内での粒界クラックの伝搬が容易になる可 能性があること ${ }^{1)}$, 更に, 残留応力の存在や破壊の原因 となる欠陥に異方性が生じることなどが考えられる21. しかし，図1の（B）に示すように切り出した， $3 \mathrm{~mm}$ 角の試験片に位置による強度差がなく, 試験片全体に一 様に引張り残留応力が存在する可能性は少ない。また, 全体の約 $93 \%$ の試験片の破壊源には潜在的な欠陥が存 在することから，上記の強度特性の差を破壊源となった 欠陥の特徴に求めてみた。図 4 は破面上に見られる破壊 源となった欠陥寸法の光学顕微鏡による測定結果であ る. 切り出し方向の差がかなり明瞭に現れ，（A）の場

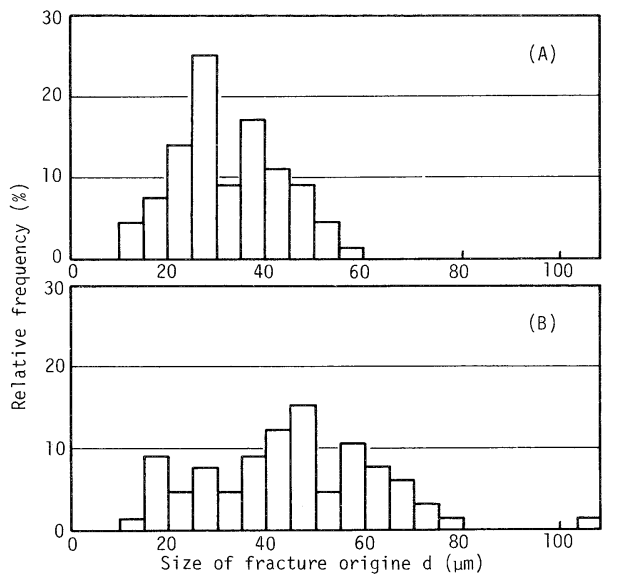

Fig. 4. Defect size distribution of hot-pressed silicon nitride.

(A) Perpendicular specimens,

(B) Parallel specimens

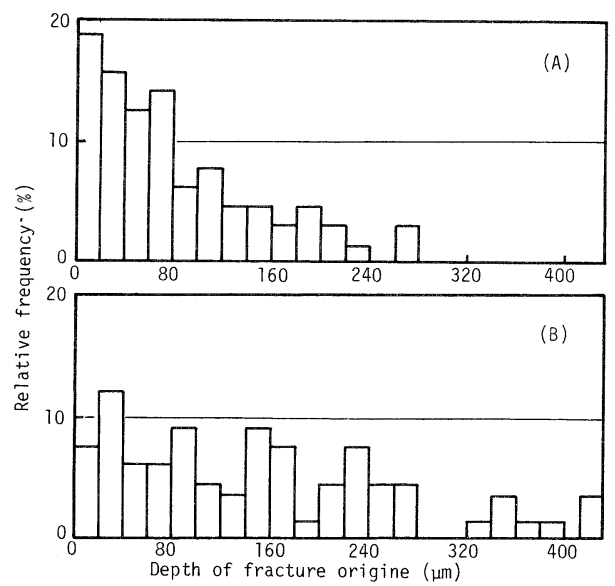

Fig. 5. Depth distribution of fracture origin. 
合の平均欠陥サイズ約 $30 \mu \mathrm{m}$ に対し，（B）では約 45 $\mu \mathrm{m}$ とかなりの差が見られるとともに寸法のばらつきも 大きいことが分かる. また, 図 5 は曲げ試験における最 大応力面からの破壊源深さの分布を示したものである. (A) では深さ $80 \mu \mathrm{m}$ までの破壊が $60 \%$ 以上であるの に比へ，（B）ではこれが約 30\% でかなり深い位置での 破壊が多く，この点からも両者の差は大きい。すなわち

（B）では欠陥サイズのばらつきが大きいため, 破壊源 となる欠陥が負荷点直下の最大応力部から離れた部分に 存在する確率が高くなることに対応していると思われ る.このように図 3 の平均強度とワイブル係数の差は破 壊源となる欠陥寸法及びそれらのばらつきの差に起因す ると考えられる。

一方, 図 6 は破壊源深さと破壊源での破壊応力の関係 を（A）と（B）の試験片を比較して示したもので, 各 深さでの破壊応力は（A）に比べて（B）では約 $20 \%$ 低い。また，図７は破壊源の深さと寸法の関係を示した ものである．深さ $60 \mu \mathrm{m}$ までの欠陥サイズのばらつき 15 40 $\mu \mathrm{m}$ に比べ， $60 \mu \mathrm{m}$ 以上の深さの久陥サイズは 15 80 $\mu \mathrm{m}$ の範囲でばらつきが大きいが，各深さ特に深 さ $60 \mu \mathrm{m}$ までの両者の欠陥寸法にはほとんど差は認め られない，すなわち，図 6 の各深さでの強度の差が久陥

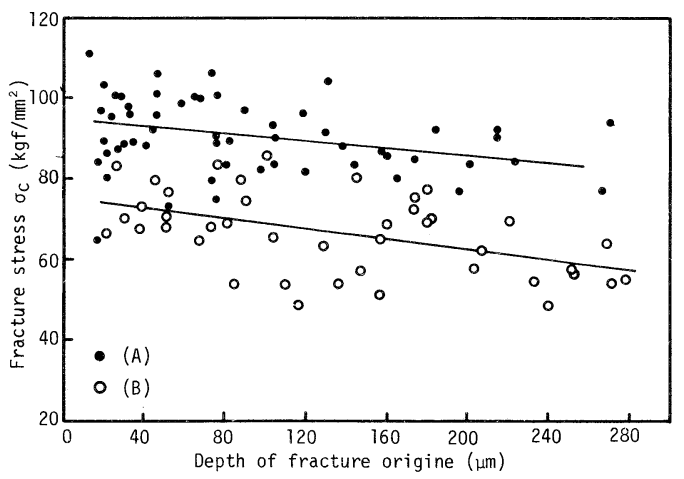

Fig. 6. Relation between the fracture stress and the depth of fracture origin.

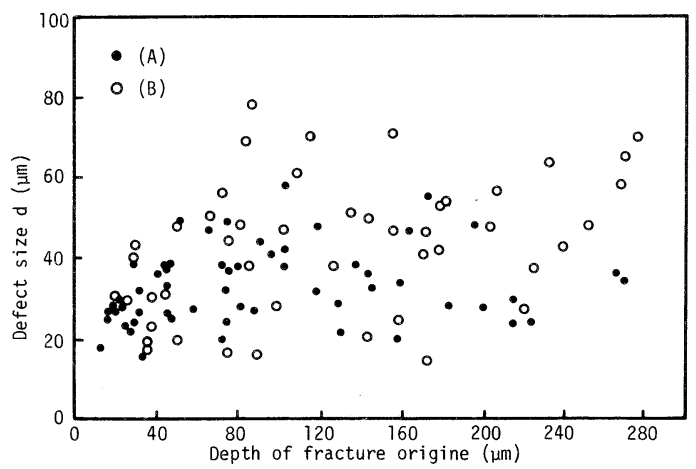

Fig. 7. Relation between the defect size and the depth of fracture origin.

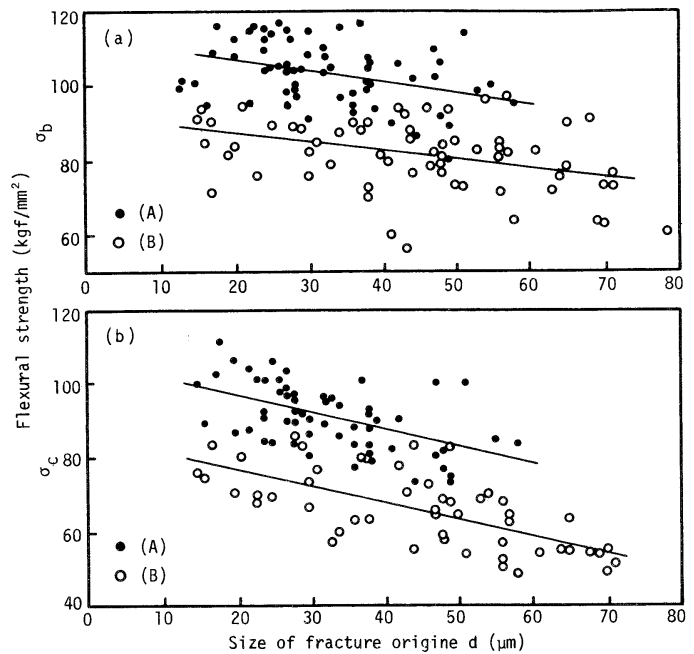

Fig. 8. Relation between the fracture stress and defect size.

(a) Flexural strength,

(b) Critical rupture stress at fracture origin

寸法の差によるとは考えられない。そこで (A)，（B） の両者について久陥寸法と強度の関係を調べた，その結 果を図 8 に示す。（a）は縦軸を曲げ強度，また（b ） はこれを破壊源の位置で補正した破壊応力として示して ある。

（a ）（b ）ともに欠陥寸法之破壊応力との間にある 程度の相関性が認められることから，欠陥寸法の大きい （B）での平均強度の低下が考えられるが，それ以上に （A）と（B）では同一欠陥寸法でも破壊応力に $20 \%$ 程度の差が見られる．この傾向は（a ），（b）とも同様 である.すなわち，プレス方向に切り出した試験片での 破壊源は，全般的にその寸法が大きいだけでなく，同一 寸法の欠陥がプレス方向に直角な方向に切り出した試験 片の欠陥より低応力下で破壊に至ることを示している.

欠陥サイズのばらつきや欠陥サイズと強度の関係を示 すこれらの結果は, 久陥形状の異方性化を示すもの之考 えられる．すなわち，焼結時の一軸圧縮応力により欠陥 が圧縮方向に偏平化し，圧縮軸方向の引張り応力に対し ては欠陥先端の曲率半径が減少し，破壊応力が低下する と考えられる，なお，球状欠陥を仮定し，破壊応力の変 化が応力集中係数の変化に対応するとすれば, 上の強度 低下は球状欠陥がプレス方向につぶされ $27 \%$ 偏平化し たことを示している。

以上の上うに，欠陥形状に異方性を持つ可能性のある ホットプレス焼結体では負荷方向と強度特性の間には密 接な関係があり，セラミック部品の設計においてはこの 点が十分配慮される必要があることを示している。 


\section{4. 結 論}

ホットプレス窒化ケイ素のブロックにおいて, 切り出 し位置，切り出し方向を異にする試験片の強度を調べ， その破面観察を行った結果，次のような結論を得た。

（1）試験片の切り出し方向が一定であれば，すなわ ち負荷方向を一定にして強度を測定すれば，ブロック内 の場所による平均強度値の変動はほとんど見られない。

（2）切り出し方向がプレス方向とこれに垂直な方向
では，欠陥サイズの分布が異なるうえ，同一寸法の欠陥 でも破壊に至る応力值に差があり，この結果，平均強度， ワイブル係数とも異なった值を示した．その原因として はプレス時における欠陥の変形が考えられた.

文 献
1) F. F. Lange, J. Am. Ceram. Soc., 56, 10 (1973).
2) 岩崎秀夫, セラミックス, 12, $342(1977)$. 